\title{
CHROMOSOME ABNORMALITIES IN RABBIT PREIMPLANTATION BLASTOCYSTS INDUCED BY SUPEROVULATION*
}

\author{
S. FUJIMOTO, $\uparrow$ N. PAHLAVAN AND W. R. DUKELOW \\ Endocrine Research Unit, Michigan State University, \\ East Lansing, Michigan 48824, U.S.A.
}

(Received 7th December 1973)

While there are undoubtedly multiple causes of spontaneous abortion and congenital birth defects, high incidences of chromosomal abnormalities in human abortuses (Carr, 1965; Geneva Conference, 1966; Makino \& coauthors, 1967; Ikeuchi, Sasaki, Kohno, Hayata \& Fujimoto, 1972), and in early embryos of the pig (McFeely, 1967) suggest that chromosomal imbalance may be one of the primary causes of early embryonic death.

Excessive administration of HCG has been reported to affect sperm capacitation in rabbits (Soupart, 1967; Wettemann \& Hafs, 1970), and the development of the zona pellucida in baboons (Katzberg \& Hendrickx, 1966). Recently, a high incidence of triploid embryos has been associated with PMSG-HCGinduced superovulation in mice (N. Takagi, personal communication).

The present investigation was conducted to study the effect of superovulation on the karyological constitution of preimplantation rabbit blastocysts.

Nine mature nulliparous female rabbits from 6 to 8 months of age and of mixed breeding were mated to fertile males 4 days after an intramuscular injection of 100 i.u. PMSG (Lilly Laboratories). Immediately after mating, the females received an intravenous injection of 100 i.u. HCG (A.P.L. Ayerst Laboratories). Ovulation and fertilization are assumed to have occurred $10 \mathrm{hr}$ later (Harper, 1963). Six additional females received saline injections as controls. All does were caged separately for at least 4 weeks before mating. Leucocytes from fifteen females and three males were cultured for chromosomal analysis.

The uterine horns were flushed with warm saline for the recovery of intact preimplantation blastocysts at 5 to 7 days of pregnancy. After size determination, by a filar micrometer eyepiece, the blastocysts were separately placed in fresh culture medium (TC-199) to which colchicine $(0.5 \mu \mathrm{g} / \mathrm{ml})$ had been added. Following incubation for $1 \frac{1}{2} \mathrm{hr}$ at $37^{\circ} \mathrm{C}$ in $5 \% \mathrm{CO}_{2}$ in air, chromosome preparations were made by a modification of the method of Shaver \& Carr (1967). The total numbers of blastocyst cells and the mitotic indices were determined for each blastocyst as we have previously reported (Fujimoto,

* Michigan Agriculture Experiment Station Journal Article Number 6641.

$\dagger$ Present address: Department of Obstetrics and Gynecology, Hokkaido University School of Medicine, Sapporo, Japan. 
Pahlavan \& Dukelow, 1973). Karyotypes were prepared according to the rabbit idiogram of Nichols, Levan, Hansen-Melander \& Melander (1965). The numbering of the autosomal pairs followed that of Shaver \& Carr (1967).

The peripheral blood leucocyte cultures from the three males and fifteen females yielded no cells with abnormal karyotypes.

A total of 187 blastocysts was observed from the fifteen does, which included the control group (Table 1). Of the ova ovulated, 73.9\% (147/199) in the superovulation group and $86.9 \%(40 / 46)$ in the control group were observed as blastocysts (Table 1).

Seventy-two and thirty-six intact blastocysts were used for karyological examinations from the experimental and control group, respectively. As shown in Table 1, seven chromosomally abnormal blastocysts $(9.7 \%)$ were found in the experimental group. In the control group, no chromosomal abnormalities were observed. The abnormal cytological features are summarized in Table 2. They included three triploids, a mosaic, a monosomy, a trisomy, and a sex chromosome chimaera.

Table 1. Numbers of corpora lutea and blastocysts, and their chromosome analysis, following collection from does subjected to superovulation or control does

\begin{tabular}{|c|c|c|c|c|c|c|c|c|c|}
\hline \multirow[b]{2}{*}{ Treatment } & \multirow{2}{*}{$\begin{array}{c}\text { Days of } \\
\text { pregnancy }\end{array}$} & \multirow{2}{*}{$\begin{array}{l}\text { No. of } \\
\text { rabbits }\end{array}$} & \multirow{2}{*}{$\begin{array}{c}\text { No. of } \\
C L\end{array}$} & \multicolumn{6}{|c|}{ No. of blastocysts } \\
\hline & & & & $\begin{array}{c}\text { Ob- } \\
\text { served }\end{array}$ & $\begin{array}{l}\text { Exam- } \\
\text { ined }\end{array}$ & $\begin{array}{l}\text { Normal } \\
44 X Y\end{array}$ & $\begin{array}{l}\text { Normal } \\
44 X X\end{array}$ & $\begin{array}{l}\text { Abnor- } \\
\text { mal }\end{array}$ & Abnormality \\
\hline \multirow[t]{3}{*}{$\begin{array}{l}\text { Super- } \\
\text { ovulation }\end{array}$} & $\begin{array}{l}5 \\
6\end{array}$ & $\begin{array}{l}5 \\
3\end{array}$ & $\begin{array}{r}106 \\
79\end{array}$ & $\begin{array}{l}70 \\
69\end{array}$ & $\begin{array}{l}32 \\
35\end{array}$ & $\begin{array}{l}16 \\
13\end{array}$ & $\begin{array}{l}15 \\
17\end{array}$ & $\begin{array}{l}1 \\
5\end{array}$ & 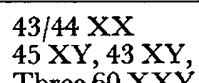 \\
\hline & 7 & 1 & 14 & 8 & 5 & 3 & 1 & 1 & $44 \mathrm{XX} / 44 \mathrm{XY}$ \\
\hline & Total & 9 & 199 & 147 & 72 & 32 & 33 & 7 & \\
\hline \multirow[t]{2}{*}{ Control } & $\begin{array}{l}5 \\
6\end{array}$ & $\begin{array}{l}3 \\
3\end{array}$ & $\begin{array}{l}28 \\
18\end{array}$ & $\begin{array}{l}25 \\
15\end{array}$ & $\begin{array}{l}24 \\
12\end{array}$ & $\begin{array}{r}14 \\
5\end{array}$ & $\begin{array}{r}10 \\
7\end{array}$ & $\begin{array}{l}0 \\
0\end{array}$ & $\begin{array}{l}\text { None } \\
\text { None }\end{array}$ \\
\hline & Total & 6 & 46 & 40 & 36 & 19 & 17 & 0 & None \\
\hline
\end{tabular}

Three triploid blastocysts had an XXY sex chromosome constitution. Plate 1, Fig. 1 shows the metaphase plate and karyotype of a triploid blastocyst.

In the mosaic blastocysts $(43 / 44 \mathrm{XX})$, the diploid cell population had a female sex chromosome complex, and in karyotypes prepared from metaphases with 43 chromosomes, the missing chromosome was found to be one of the small subtelocentric chromosomes (pair 18). Karyotypes of a trisomic blastocyst showed an extra large acrocentric chromosome (pair 20). A monosomic blastocyst lacked one large submetacentric chromosome (possibly pair 9). A chimaera blastocyst had eight female and nine male sex chromosome complexes out of seventeen diploid cell karyotypes (Pl. 1, Fig. 2).

The five abnormal blastocysts, except for the two cases of $43 / 44 \mathrm{XX}$ and $45 \mathrm{XY}$, had fewer blastomere numbers and lower mitotic indices than the normal diploid litter mates (Fujimoto et al., 1973). 


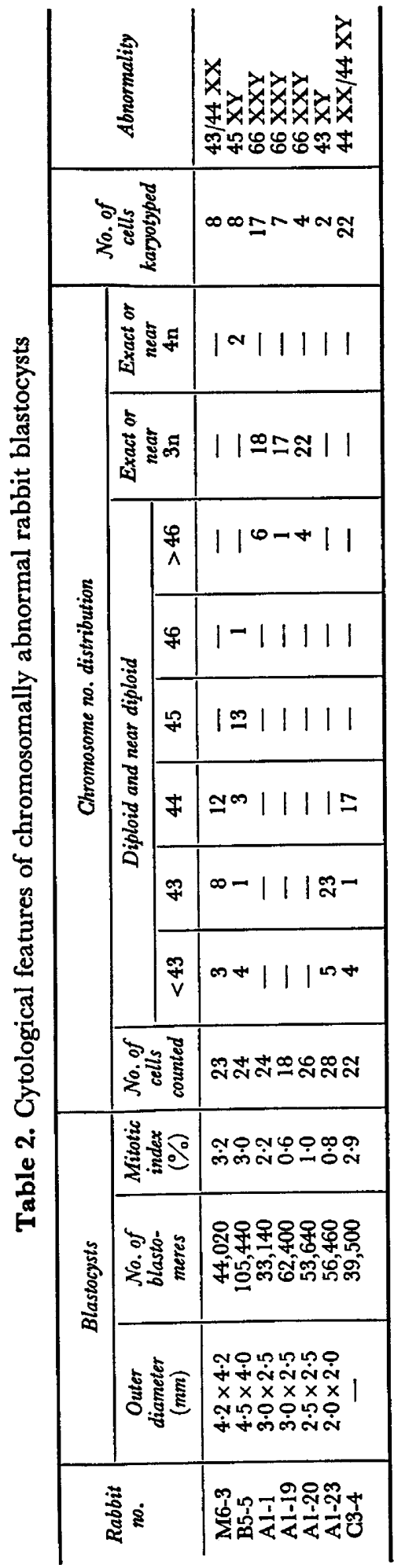


The outer diameters of the one monosomic and three triploid blastocysts were also reduced compared to those from normal diploid litter mates.

Kennelly \& Foote (1965) reported no differences in the fertilization rate of does which had or had not been subjected to superovulation and had been inseminated immediately after HCG administration. Tesh (1966) suggested, however, that superovulated eggs were in some way deficient, and reported a decreased fertilization rate in such does with spermatozoa aged in vivo.

In mice, superovulation may give rise to fewer litters and to abnormal pregnancies (Fowler \& Edwards, 1957). Recently, high incidences of triploid conceptuses have been reported in pregnant mice following superovulation (N. Takagi, personal communication).

In rabbits, Shaver \& Carr (1969) reported no significant difference in the incidence of chromosomal abnormalities of blastocysts collected following natural mating with and without HCG injection (25 i.u.). Shaver (1970) also gave no indication that excess HCG (75 to $300 \mathrm{i}$.u.) adversely affected the chromosomal constitution of developing ova, reporting only two abnormalities (43/44 XY and $44 \mathrm{XY}$ with deletion of the short arm of a submetacentric chromosome) among the seventy-five blastocysts examined. The ovulation rates in those reports, however, were $10.5(287 / 27)$ and $10.0(110 / 10)$, respectively; while that of our present data was 22.1 (199/9), which was assumed to be superovulatory. The percentage recovery (number of observed blastocysts) in the superovulation group $(73.9 \%$ ) was less than in the control group $(86.9 \%)$ and also less than the levels reported by Martin \& Shaver (1972) and Widmeyer \& Shaver (1972) and might be due to the effect of the superovulation (Table 1).

The effects of delayed fertilization have been studied in various species. In rabbits, when mating was delayed between 6 and $9 \mathrm{hr}$ after injection of HCG (25 i.u.), $13 \%$ of the blastocysts were found to be triploid, but no triploids were observed with delay intervals of 0 to $4 \mathrm{hr}$ (Shaver \& Carr, 1969). Our previous laparoscopic study concerning hormonal influence on the time of ovulation in rabbits (Fujimoto, Rawson \& Dukelow, 1974) should, however, eliminate the possibility of delayed fertilization.

The incidences of chromosomally abnormal blastocysts of rabbits mated naturally without any gonadotrophins were reported as 2.0\% $(1 / 58)$ (Shaver \& Carr, 1969), and 1.4\% (1/72) (Widmeyer \& Shaver, 1972).

We agree with the suggestion of Hansen-Melander \& Melander (1970) that blastocysts obtained following superovulation are not suitable as test subjects for many types of reproductive studies.

Induction of superovulation by PMSG and HCG has been widely adopted for obtaining a large number of eggs or conceptuses from laboratory animals. The results of the present study indicate the need to consider the possible

\section{EXPLANATION OF PLATE 1}

Fig. 1. Metaphase plate and karyotype of a triploid blastocyst (Rabbit Al-19, 66XXY) collected from a doe following induction of superovulation with PMSG and HCG.

Figs 2 and 3. Karyotypes of a chimaera blastocyst collected from Rabbit G3-4 following induction of superovulation with PMSG and HCG.

Fig. 2. Karyotype with $44 \mathrm{XX}$ chromosomes.

Fig. 3. Karyotype with $44 \mathrm{XY}$ chromosomes. 


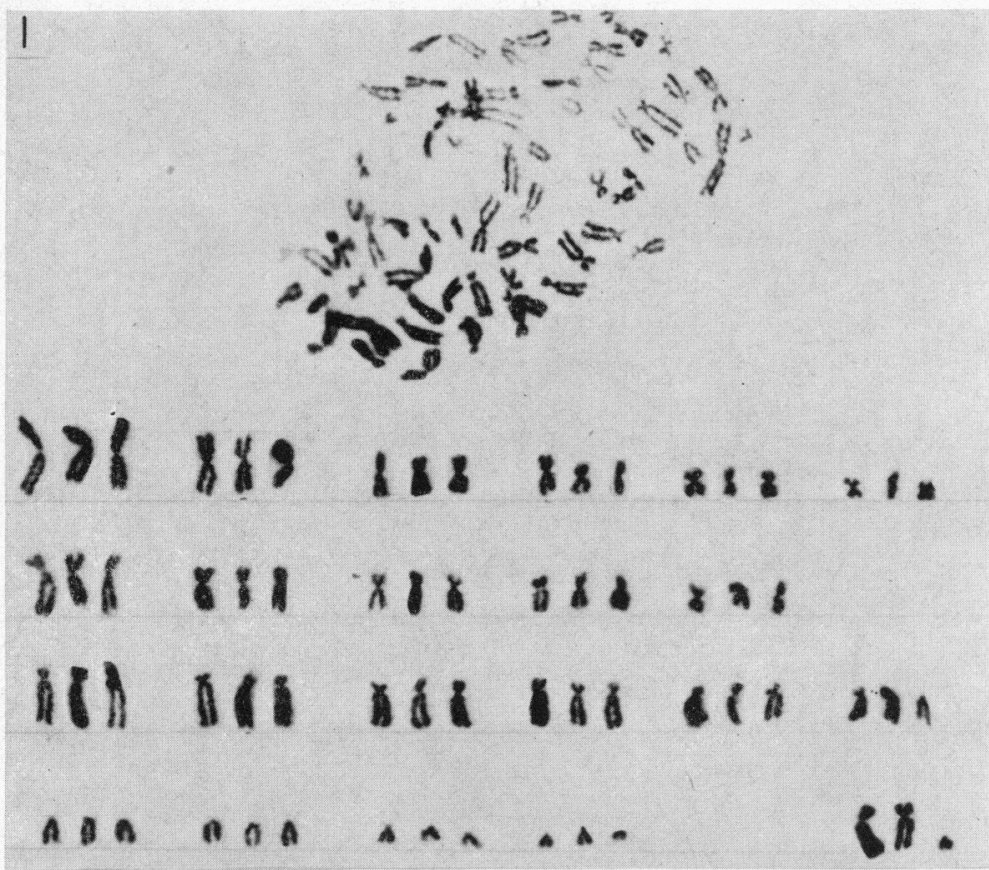

2 II

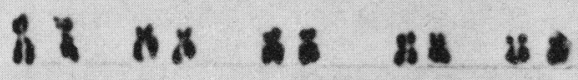

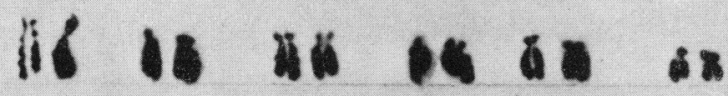

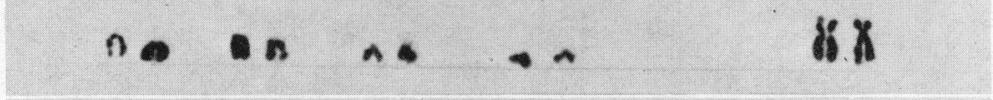

${ }^{3} 1888 \times 8$ 86 $x=2$.

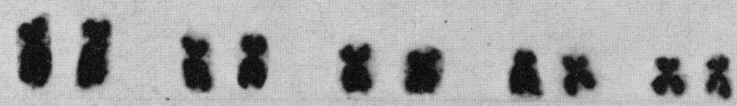

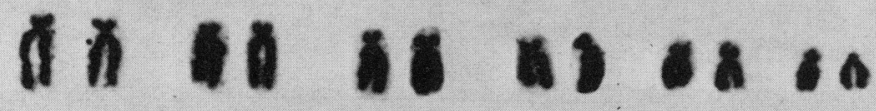

a na a n

(Facing p. 180) 
genetic effects of superovulation on ovum maturation, fertilization and early growth of embryos.

This work was supported by NIH Research Career Development Award No. 1-K4-HD 35,306, and a grant from the National Foundation-March of Dimes.

\section{REFERENCES}

GARR, D. H. (1965) Ghromosome studies on spontaneous abortion. Obstet. Gynec., N.Y. $26,308$.

Fowler, R. E. \& EDwards, R. G. (1957) Induction of superovulation and pregnancy in mature mice by gonadotrophins. F. Endocr. 15, 374 .

Fujmoto, S., Pahlavan, N. \& Dukelow, W. R. (1973) A simplified method for the determination of the blastomere numbers in preimplantation rabbit blastocysts. $\mathcal{F}$. Reprod. Fert. 34, 369.

Fujimoto, S., Rawson, J. M. R. \& Dukelow, W. R. (1974) Hormonal influence of ovulation in the rabbit as determined by laparoscopy. $\mathcal{F}$. Reprod. Fert. 38, 97.

Geneva Conference (1966) Standardization of procedures for chromosome studies in abortion. Bull. Wld Hlth Org. 34, 765.

Hansen-Melander, E. \& Melander, Y. (1970) The rabbit blastocyst as test object for environmental influences on mammalian chromosomes. Hereditas, 65, 237.

Harper, M. J. K. (1963) Ovulation in the rabbit: the time of follicular rupture and expulsion of the eggs, in relation to injection of luteinizing hormone. F. Endocr. 26, 307.

Ixeuchi, T., Sasaki, M., Kohno, S., Hayata, I. \& Fujmoto, S. (1972) Ghromosome studies on spontaneous and threatened abortions. Jap. 7. hum. Genet. 16, 191.

Katzberg, A. A. \& Hendrickx, A. G. (1966) Gonadotropin-induced anomalies of the zona pellucida of the baboon ovum. Science, N.Y. 151, 1225.

Kennelly, J. J. \& Foote, R. H. (1965) Superovulatory responses of pre- and post-pubertal rabbits to commercially available gonadotrophins. F. Reprod. Fert. 9, 177.

McFeely, R. A. (1967) Ghromosome abnormalities in early embryos of the pig. 7. Reprod. Fert. $13,579$.

Makino S., Ikeuchi, T., Sasaki, M., Muramoto, J., Shimba, H., Fujlmoto, S. \& Matsuda, S. (1967) A preliminary study of the chromosomes in spontaneous abortions. Proc. Japan Acad. 43, 552.

Martin, P. A. \& Shaver, E. L. (1972) Sperm aging in utero and chromosomal anomalies in rabbit blastocysts. Devl Biol. 28, 480.

Nichols, W. W., Levan, A., Hansen-Melander, E. \& Melander, Y. (1965) The idiogram of the rabbit. Hereditas, 53, 63.

Shaver, E. L. (1970) The chromosome complement of blastocysts from rabbits injected with various doses of HCG before ovulation. 7. Reprod. Fert. 23, 335.

Shaver, E. L. \& CARR, D. H. (1967) Chromosome abnormalities in rabbit blastocysts following delayed fertilization. F. Reprod. Fert. 14, 415.

Shaver, E. L. \& GARR, D. H. (1969) The chromosome complement of rabbit blastocysts in relation to the time of mating and ovulation. Can. F. Genet. Cytol. 11, 287.

Soupart, P. (1967) Studies on the hormonal control of rabbit sperm capacitation. 7. Reprod. Fert., Suppl. 2, 49.

Tesh, J. M. (1966) Effect of time of insemination and superovulation on fertilization in the rabbit. 7. Endocr. 35, xxviii.

Wettemann, R. P. \& Hafs, H. D. (1970) Sperm capacitation after injection of LH or HCG in rabbits. Proc. Soc. exp. Biol. Med. 133, 1002.

Widmeyer, M. A. \& Shaver, E. L. (1972) Estrogen, progesterone and chromosome abnormalities in rabbit blastocysts. Teratology, 6, 207. 